\title{
Complications, clinical manifestations of congenital syphilis, and aspects related to its prevention: an integrative review
}

\author{
Complicações, manifestações clínicas da sífilis congênita e aspectos relacionados à prevenção: revisão integrativa
}

Complicaciones, manifestaciones clínicas de la sífilis congénita y aspectos relacionados a la prevención: revisión integrativa

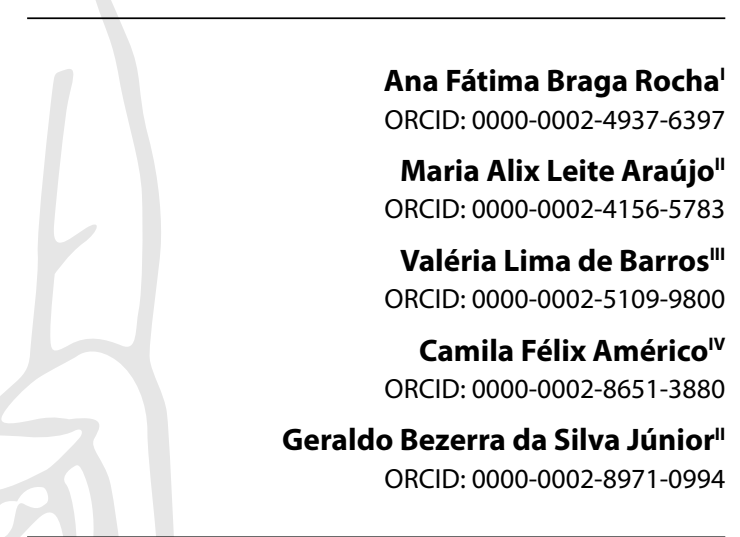

'Faculdade Terra Nordeste. Fortaleza, Ceará, Brazil. "Universidade de Fortaleza. Fortaleza, Ceará, Brazil.

"'Universidade Federal do Piauí. Picos, Piauí, Brazil. "Universidade Federal do Ceará. Fortaleza, Ceará, Brazil.

How to cite this article:

Rocha AFB, Araújo MAL, Barros VL, Américo CF, Silva Jr GB. Complications, clinical manifestations of congenital syphilis, and aspects related to its prevention: an integrative review. Rev Bras Enferm. 2021;74(4):e20190318. https://doi.org/10.1590/0034-7167-2019-0318

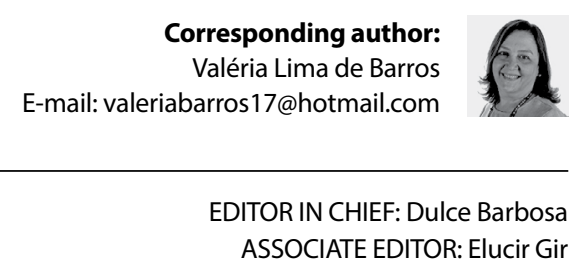

Submission: 07-17-2019

Approval: 04-18-2021

\begin{abstract}
Objectives: to identify the scientific evidence about the clinical complications and manifestations of congenital syphilis and aspects related to its prevention. Methods: integrative review after a search in the databases LILACS and MEDLINE, carried out in March 2018, using the descriptors "syphilis, congenital","complications", and "signs and symptoms", leading to the selection of 27 researches. Results: the publications found were published from 1966 to 2017, and most of them were from Latin America and Africa. Negative outcomes, laboratory changes, and the clinical manifestations in congenital syphilis, whether early or delayed, were, respectively: low weight at birth, anemia, hepatosplenomegaly, and dental alterations. The lack of treatment of the pregnant women in the prenatal was the most common occasion in which the opportunity to prevent the complications of congenital syphilis was lost. Conclusions: the scientific evidences analyzed showed serious complications of congenital syphilis that could be avoided if early opportunities of diagnosing and treating the pregnant women are not lost during the prenatal. Descriptors: Congenital Syphilis; Sings and Symptoms; Complications; Syphilis; Prenatal Care.
\end{abstract}

\section{RESUMO}

Objetivos: identificar as evidências científicas acerca das complicações e manifestações clínicas da sífilis congênita e aspectos relacionados à prevenção. Métodos: revisão integrativa, mediante busca nas bases de dados LILACS e MEDLINE, realizada em março de 2018, utilizando os descritores "syphilis, congenital", "complications", "signs and symptoms", resultando em 27 pesquisas selecionadas. Resultados: encontraram-se publicações entre os anos de $1966 \mathrm{e}$ 2017, na maioria oriundas da América Latina e África. O desfecho desfavorável, a alteração laboratorial e as manifestações clínicas da sífilis congênita precoce e tardia mais evidenciados foram, respectivamente, baixo peso ao nascer, anemia, hepatoesplenomegalia e alterações odontológicas. Observou-se que a falta de tratamento da gestante no pré-natal foi a principal oportunidade perdida de prevenção das complicações da sífilis congênita. Conclusões: as evidências científicas analisadas apresentam graves complicações da sífilis congênita que seriam evitadas desde que oportunidades precoces de diagnóstico e tratamento da gestante não fossem perdidas durante o pré-natal.

Descritores: Sífilis Congênita; Sinais e Sintomas; Complicações; Sífilis; Cuidado Pré-Natal.

\section{RESUMEN}

Objetivos: identificar evidencias científicas sobre las complicaciones y manifestaciones clínicas de la sífilis congénita y aspectos relacionados a prevención. Métodos: revisión integrativa, mediante búsqueda en bases de datos LILACS y MEDLINE, realizada en marzo de 2018, utilizando los descriptores "syphilis, congenital", "complications", "signs and symptoms", resultando en 27 investigaciones seleccionadas. Resultados: encontraron publicaciones entre 1966 y 2017, la mayoría oriundas de Latinoamérica y África. Desfecho desfavorable, la alteración laboratorial y manifestaciones clínicas de la sífilis congénita precoz y tardía más evidenciados fueron, respectivamente, bajo peso al nacer, anemia, hepatoesplenomegalia y alteraciones odontológicas. Observó que la falta de tratamiento de la embarazada en el prenatal fue la principal oportunidad perdida de prevención de las complicaciones de la sífilis congénita. Conclusiones: las evidencias científicas analizadas presentan graves complicaciones de la sífilis congénita que serían evitadas desde que oportunidades precoces de diagnóstico y tratamiento de la embarazada no fueran perdidas durante el prenatal. Descriptores: Sífilis Congénita; Signos y Síntomas; Complicaciones; Sífilis; Atención Prenatal. 


\section{INTRODUCTION}

Despite all attempts to eliminate congenital syphilis (CS) as a public health problem, estimates show that the disease affects a million pregnant women every year throughout the world. When it is not adequately treated, it can cause more than 300 thousand fetal and neonate deaths, putting nearly 200 thousand children under the risk of an untimely death ${ }^{(1-3)}$.

The morbidity and mortality by CS are avoidable and sensible to the health care conditions of women and children. An in-depth investigation about the aspects involved in the transmission of syphilis from mother to child is useful to identify the facts that determine and put children under the risk of sequelae and death, not to mention that an investigation of the kind could aid in the development of strategies to prevent and control the disease.

Brazil is a subscriber of the United Nations Sustainable Development Goals (SDG) $)^{(4)}$, which include controlling CS and eliminating the avoidable deaths of newborns and children below 5 years old. In countries where the prevalence of CS is high, the eradication of such a public health problem would have a positive impact, helping to achieve these goals.

The importance of controlling CS is especially related to the complications that this infection can cause in babies ${ }^{(5-7)}$. Although most children are asymptomatic at the time of birth ${ }^{(8)}, \mathrm{CS}$ can manifest early, up to their second year of age, or late, after this period. The symptoms usually can be dermatological, osseous, ophthalmic, auricular, neurological, or dental, in addition to alterations that can be found by laboratory exams ${ }^{(9)}$.

Considering the problem posed to the world by the current CS epidemic, it is extremely important to divulge the clinical complications and manifestations that this infection can cause in babies, including identifying factors that can help avoiding them.

\section{OBJECTIVES}

To identify the scientific evidence about the complications and clinical manifestations of CS and the aspects related to prevention.

\section{METHODS}

This is an integrative literature review, designed with the following steps: definition of a research question, search or sampling in literature (after defining inclusion and exclusion criteria), categorization of the information extracted, evaluation of the studies selected, interpretation of the results, and, finally, presentation of a review/synthesis of the knowledge provided ${ }^{(10-11)}$.

The problem addressed by the review (the research question) was determined using the PICO strategy: $\mathrm{P}$ (population): pregnant women and children; I (interest): congenital syphilis; $\mathrm{O}$ (outcome): clinical complications and manifestations. The letter $C$, representing "comparison", does not apply to this research. As a result, the following guiding question was formed: What are the scientific evidences about complications and clinical CS manifestations, and what other studies have found about aspects related to prevention?

The online search was carried out in the Virtual Health Library (VHL), in the databases Latin American and Caribbean Health Sciences Literature (LILACS) and Medical Literature Analysis and Retrieval System Online (MEDLINE). Studies were selected in March
2018, using two crossed pairings of the three health descriptors (DeCS/MeSH: 1) "syphilis, congenital" AND "complications"; 2) "syphilis, congenital" AND "signs and symptoms". The limiting boolean operator "AND" was used to restrict the search only to findings about CS complications and clinical manifestations.

The inclusion criteria considered the following characteristics: original articles, available in full, and published in Portuguese, English, or Spanish. The systematic review and meta-analysis articles were also included, since some journals consider these to be original articles. Since syphilis has existed for millennia, with repercussions all around the globe, the year of publication of the investigations was not restricted, allowing for a broad survey of literature. Abstracts, editorials, letters to the editors, technical information, previous notes, repeated articles, and those that were not in accordance with the objective of this study were excluded.

The initial search for articles found 1,982 results. From these, 1,390 were excluded because they were not available in-full or were not in Portuguese, English, nor Spanish. Furthermore, 77 were duplicates, and as a result, were discarded. The titles and abstracts were read and, when the article seemed to be a potential inclusion, its results were skimmed. This allowed for the selection of 27 articles to be read in full and categorized for an analysis. The results were interpreted, and the final presentation of the review took place (Figure 1).

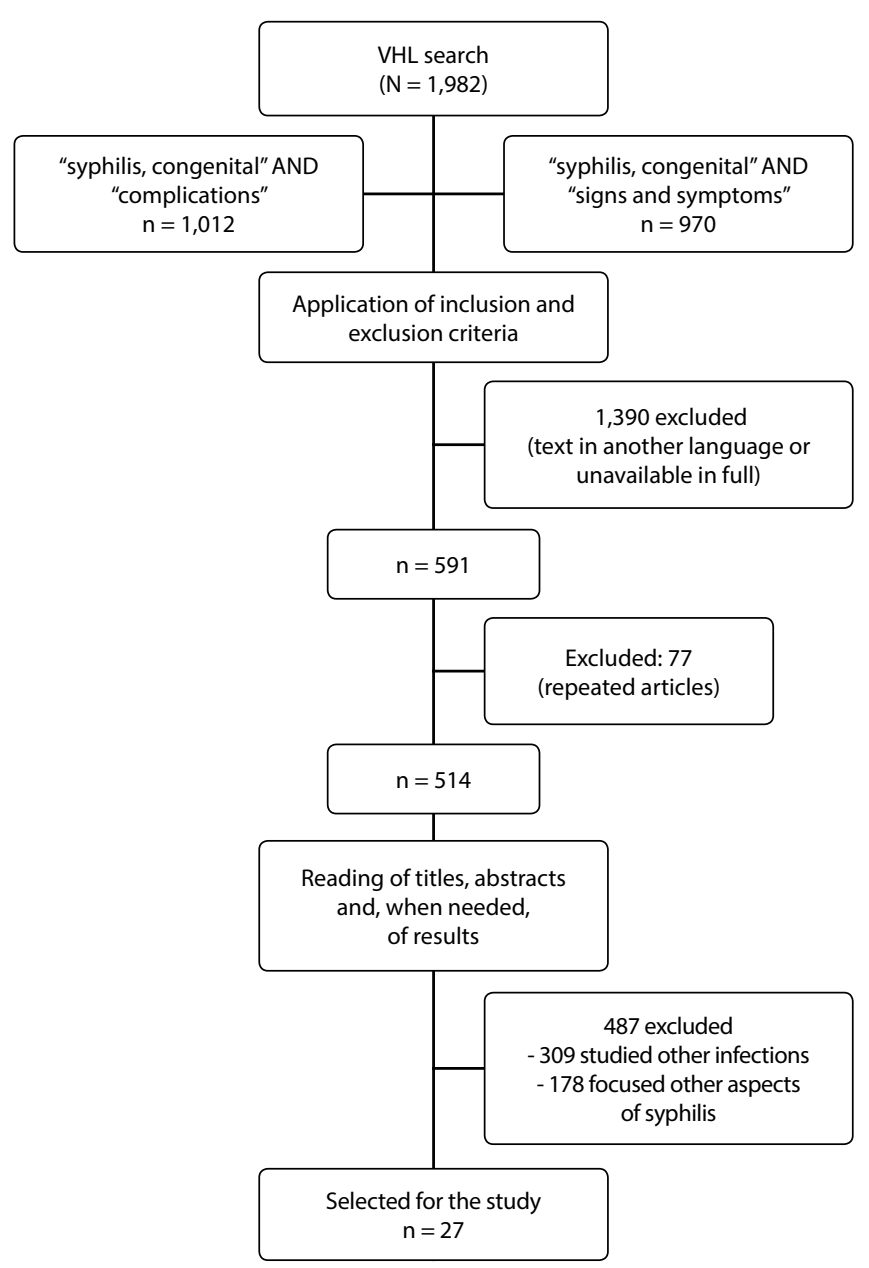

Note: VHL - Virtual Health Library.

Figure 1 - Flowchart of article selection, according to the search for descriptors and for the inclusion criteria proposed 
To diminish potential biases, two researchers selected, independently, studies for the analysis. A third researcher was also participating, to help deciding on the inclusion or inclusion of articles whenever there were disagreements.

The studies were presented using tables that included identification data, methodological characteristics, evidence levels ${ }^{(12)}$, results, and conclusions. Considering the variety of complications and clinical manifestations that were identified, the description of the results, as well as the descriptive analysis carried out to present the findings of this analysis were compiled, based on the following findings: negative outcomes, laboratory changes and radiological changes, and early and late CS manifestations.

\section{RESULTS}

Data from the studies selected for analysis show a diversity of negative outcomes, laboratory and/or radiological alterations, and early and late CS manifestations. Publications from 1966 to 2017 were found, but the interval between the earlier publications was of approximately 10 years; from 2013 on, their frequency was higher, and their number increased. Most publications originated from LatinAmerican $(n=11)$ and African countries $(n=5)$. It stands out that the most recent studies were carried out in Brazil (E1, E2, E3, E4, E6).

Most studies were descriptive and cross-sectional $(n=21)$. From the studies analyzed, only four showed some type of follow up with the children (E9, E12, E17, and E19). Two (E8 and E14) were systematic reviews, and, as a result, their level of evidence was I (Chart 1).

From the 27 studies analyzed, 18 focused on the negative outcomes of CS, such as low weight at birth $(n=11)$, stillbirths $(n=9)$, or neonate death $(n=9)$. With the exception of E8, all others had more than one outcome, including miscarriage $(n=7)$, prematurity $(n=8)$, or post-neonate death $(n=3)$. Only E14 had, in the scope of its investigation, all outcomes observed in this review (miscarriage, stillbirth, death, prematurity, and low weight at birth) (Chart 2).

Chart 1 - Characterization of articles according to authorship, year of publication, title, country, journal, level of evidence and type of study

\begin{tabular}{|c|c|c|c|c|c|c|}
\hline Code & Author/Year & Title & Country & Journal & $\begin{array}{l}\text { Level of } \\
\text { evidence }\end{array}$ & $\begin{array}{l}\text { Type of } \\
\text { study }\end{array}$ \\
\hline E1 & $\begin{array}{l}\text { Souza et al., } \\
2017^{(13)}\end{array}$ & $\begin{array}{l}\text { Analysis of congenital syphilis cases notification in a reference } \\
\text { hospital of Niteroi, Rio de Janeiro State, from } 2008 \text { to } 2015\end{array}$ & Brazil & $\begin{array}{l}\text { J Bras Doenças } \\
\text { Sex Transm. }\end{array}$ & $\mathrm{VI}$ & Descriptive \\
\hline E2 & $\begin{array}{l}\text { Cardoso et al., } \\
2016^{(14)}\end{array}$ & $\begin{array}{l}\text { Underreporting of Congenital Syphilis as a Cause of Fetal and } \\
\text { Infant Deaths in Northeastern Brazil }\end{array}$ & Brazil & PLOS ONE & VI & $\begin{array}{c}\text { Cross- } \\
\text { sectional }\end{array}$ \\
\hline E3 & $\begin{array}{l}\text { Feliz et al., } \\
2016^{(15)}\end{array}$ & $\begin{array}{l}\text { Aderência ao seguimento no cuidado ao recém-nascido } \\
\text { exposto à sífilis e características associadas à interrupção do } \\
\text { acompanhamento }\end{array}$ & Brazil & $\begin{array}{l}\text { Rev. Bras. } \\
\text { Epidemiol. }\end{array}$ & VI & Descriptive \\
\hline E4 & $\begin{array}{l}\text { Domingues; } \\
\text { Leal, } 2016^{(7)}\end{array}$ & $\begin{array}{l}\text { Incidência de sifilis congênita e fatores associados à transmissão } \\
\text { vertical da sífilis: dados do estudo Nascer no Brasil }\end{array}$ & Brazil & $\begin{array}{l}\text { Cad. Saúde } \\
\text { Pública }\end{array}$ & VI & $\begin{array}{l}\text { Cross- } \\
\text { sectional }\end{array}$ \\
\hline E5 & $\begin{array}{l}\text { Ferreira et al., } \\
2016^{(16)}\end{array}$ & Skin rash: a manifestation of early congenital syphilis & Portugal & $\begin{array}{l}\text { BMJ Case } \\
\text { Reports }\end{array}$ & VI & Case report \\
\hline E6 & $\begin{array}{l}\text { Lafetá et l., } \\
2016^{(17)}\end{array}$ & Sífilis materna e congênita, subnotificação e difícil controle & Brazil & $\begin{array}{l}\text { Rev. Bras. } \\
\text { Epidemiol. }\end{array}$ & VI & Descriptive \\
\hline E7 & $\begin{array}{l}\text { Dou et al., } \\
2016^{(18)}\end{array}$ & Epidemic Profile of Maternal Syphilis in China in 2013 & China & $\begin{array}{l}\text { BioMed } \\
\text { Research } \\
\text { International }\end{array}$ & VI & $\begin{array}{l}\text { Cross- } \\
\text { sectional }\end{array}$ \\
\hline E8 & $\begin{array}{l}\text { Arnesen; } \\
\text { Serruya; Duran, } \\
2015^{(19)}\end{array}$ & $\begin{array}{l}\text { Gestational syphilis and stillbirth in the Americas: a systematic } \\
\text { review and meta-analysis }\end{array}$ & - & $\begin{array}{l}\text { Rev Panam } \\
\text { Salud Publica }\end{array}$ & 1 & $\begin{array}{l}\text { Systematic } \\
\text { review and } \\
\text { meta-analysis }\end{array}$ \\
\hline E9 & Rac et al., 2014 20$)$ & $\begin{array}{l}\text { Progression of ultrasound findings of fetal syphilis after } \\
\text { maternal treatment }\end{array}$ & $\begin{array}{l}\text { United } \\
\text { States }\end{array}$ & $\begin{array}{l}\text { Am J Obstet } \\
\text { Gynecol. }\end{array}$ & IV & $\begin{array}{c}\text { Retrospective } \\
\text { cohort }\end{array}$ \\
\hline E10 & $\begin{array}{l}\text { Chowdhary et } \\
\text { al., 2014 }\end{array}$ & Early detection of congenital syphilis & India & $\begin{array}{l}\text { JIndian Soc } \\
\text { Pedod Prev Dent. }\end{array}$ & VI & Case report \\
\hline E11 & $\begin{array}{l}\text { Cavagnaro et al., } \\
2014^{(22)}\end{array}$ & Sífilis congénita precoz: a propósito de 2 casos clínicos & Chile & Rev Chil Pediatr. & VI & Case report \\
\hline E12 & $\begin{array}{l}\text { Lago; Vaccari; } \\
\text { Fiori, } 2013^{(8)}\end{array}$ & Clinical features and follow-up of congenital syphilis & Brazil & Sex Transm Dis. & IV & Cohort \\
\hline E13 & $\begin{array}{l}\text { Newman et al., } \\
2013^{(6)}\end{array}$ & $\begin{array}{l}\text { Global estimates of syphilis in pregnancy and associated } \\
\text { adverse outcomes: analysis of multinational antenatal } \\
\text { surveillance data }\end{array}$ & $\begin{array}{l}\text { Worldwide } \\
\text { research }\end{array}$ & PLoS Med & VI & Descriptive \\
\hline E14 & $\begin{array}{l}\text { Gomez et al., } \\
2013^{(5)}\end{array}$ & $\begin{array}{l}\text { Untreated maternal syphilis and adverse outcomes of } \\
\text { pregnancy: a systematic review and meta-analysis }\end{array}$ & - & $\begin{array}{l}\text { Bull World } \\
\text { Health Organ. }\end{array}$ & I & $\begin{array}{l}\text { Systematic } \\
\text { review and } \\
\text { meta-analysis }\end{array}$ \\
\hline E15 & $\begin{array}{l}\text { Arriagada et al., } \\
2012^{(23)}\end{array}$ & $\begin{array}{l}\text { Sifilis congénita: presentación como shock séptico después del } \\
\text { período neonatal }\end{array}$ & Chile & $\begin{array}{l}\text { Rev Chilena } \\
\text { Infectol. }\end{array}$ & $\mathrm{Vl}$ & Case report \\
\hline E16 & $\begin{array}{l}\text { Pessoa; Galvão, } \\
2011^{(24)}\end{array}$ & Clinical aspects of congenital syphilis with Hutchinson's triad & Brazil & BMJ Case Rep. & VI & Case report \\
\hline
\end{tabular}


Chart 1 (concluded)

\begin{tabular}{|c|c|c|c|c|c|c|}
\hline Code & Author/Year & Title & Country & Journal & \begin{tabular}{|c|}
$\begin{array}{c}\text { Level of } \\
\text { evidence }\end{array}$ \\
\end{tabular} & $\begin{array}{l}\text { Type of } \\
\text { study }\end{array}$ \\
\hline E17 & $\begin{array}{l}\text { Zhu et al., } \\
2010^{(25)}\end{array}$ & $\begin{array}{l}\text { Maternal and congenital syphilis in Shanghai, China, } 2002 \text { to } \\
2006\end{array}$ & China & Int J Infect Dis. & IV & Cohort \\
\hline E18 & $\begin{array}{c}\text { Kruger; } \\
\text { Malleyeck, } \\
2010^{(26)}\end{array}$ & $\begin{array}{l}\text { Congenital syphilis: still a serious, under-diagnosed threat for } \\
\text { children in resource-poor countries }\end{array}$ & Tanzania & World J Pediatr. & $\mathrm{Vl}$ & Descriptive \\
\hline E19 & $\begin{array}{c}\text { Reyes et al., } \\
2004^{(27)}\end{array}$ & $\begin{array}{l}\text { Sifilis congénita: Optimizando el diagnóstico en } 191 \text { neonatos de } \\
\text { madres seropositivas }\end{array}$ & Chile & $\begin{array}{l}\text { Rev. chil. } \\
\text { infectol. }\end{array}$ & IV & Cohort \\
\hline E20 & $\begin{array}{l}\text { Peña et al., } \\
2001^{(28)}\end{array}$ & Presentación de un caso y revisión de la literatura & Mexico & $\begin{array}{l}\text { Rev. méd. Hosp. } \\
\text { Gen. Méx. }\end{array}$ & $\mathrm{VI}$ & Case report \\
\hline E21 & $\begin{array}{l}\text { McDermott et } \\
\text { al., 1993 }\end{array}$ & $\begin{array}{l}\text { Syphilis-associated perinatal and infant mortality in rural } \\
\text { Malawi }\end{array}$ & Malawi & $\begin{array}{l}\text { Bull World } \\
\text { Health Organ. }\end{array}$ & IV & $\begin{array}{c}\text { Cross- } \\
\text { sectional }\end{array}$ \\
\hline E22 & $\begin{array}{l}\text { Boot et al., } \\
1989^{(30)}\end{array}$ & $\begin{array}{l}\text { Congenital syphilis in The Netherlands: diagnosis and clinical } \\
\text { features }\end{array}$ & Netherlands & Genitourin Med. & $\mathrm{VI}$ & Descriptive \\
\hline E23 & $\begin{array}{c}\text { Chawla et al., } \\
1988^{(31)}\end{array}$ & Congenital syphilis in the newborn & Zimbabwe & Arch Dis Child. & VI & Descriptive \\
\hline E24 & $\begin{array}{c}\text { Ewing et al., } \\
1985^{(32)}\end{array}$ & Early congenital syphilis still occurs & England & Arch Dis Child. & $\mathrm{VI}$ & Descriptive \\
\hline E25 & $\begin{array}{l}\text { Aguayo T et al., } \\
1985^{(33)}\end{array}$ & Síndrome nefrótico secundario a lúes congénita & Chile & $\begin{array}{l}\text { Rev. Chil. } \\
\text { Pediatr. }\end{array}$ & VI & Case report \\
\hline E26 & $\begin{array}{l}\text { Wiggelinkhuizen } \\
\text { et al., } 1973^{(34)} \\
\end{array}$ & $\begin{array}{l}\text { Congenital syphilis and glomerulonephritis with evidence for } \\
\text { immune pathogenesis }\end{array}$ & $\begin{array}{l}\text { South } \\
\text { Africa }\end{array}$ & Arch Dis Child. & VI & Case report \\
\hline E27 & $\begin{array}{l}\text { Freiman; Super, } \\
\qquad 1966^{(35)}\end{array}$ & $\begin{array}{l}\text { Thrombocytopenia and congenital syphilis in South African } \\
\text { Bantu infants }\end{array}$ & $\begin{array}{l}\text { South } \\
\text { Africa }\end{array}$ & Arch Dis Child. & $\mathrm{VI}$ & Descriptive \\
\hline
\end{tabular}

Fourteen articles found children with laboratory and/or radiological alterations related to CS. The most common alteration was anemia, which was detected in 11 studies, followed by thrombocytopenia ( $n=8)$, and leukocytosis $(n=7)$. It stands out that, in half of these articles, there were high levels of proteins and/or leukocytes in the newborns' liquor, and the Venereal Disease Research Laboratory (VDRL) was reactive. Regarding radiological findings, ten publications found changes in long bones, such as periostitis, osteochondritis, osteomyelitis, or Wimberger's sign (Chart 2).

Clinical CS manifestations were the focus of 18 studies. It stands out that the CS manifested early in 15 cases and late in 3 . In this context, data relative to the early infection symptoms were predominant $(\mathrm{n}=$ $16)$, such as hepatomegaly and/or splenomegaly $(n=14)$, in addition to skin lesions with desquamation, consistent with palmoplantar pemphigus $(n=12)$. Other traits that stand out are the presence of jaundice $(n=9)$; purulent, serosanguineous and thick nose secretions $(n=7)$; perioral or perianal fissures/tears $(n=5)$; and petechia, purpura, and/or rashes $(n=5)$. Regarding late $C S$, it manifested in ophthalmic (interstitial keratitis), auricular (neurological deafness/ hearing loss), osseous (frontal bossing and saddle nose), and dental (Hutchinson's teeth and mulberry molars) issues. Only E12, a cohort, discussed both types of manifestation (Chart 2).

Chart 2 - Clinical complications and manifestations of congenital syphilis addressed in the studies analyzed

\begin{tabular}{|c|c|c|}
\hline $\begin{array}{l}\text { Complications and manifestations of } \\
\text { congenital syphilis }\end{array}$ & & Analyzed studies $(n=27)$ \\
\hline Negative outcomes & Number of studies & Code of the studies with negative outcomes* $(n=18)$ \\
\hline Miscarriage/fetal death & 07 & E1;E2; E4; E6; E13; E14; E17 \\
\hline Stillbirth & 09 & $E 1 ; E 2 ; E 6 ; E 7 ; E 8 ; E 12 ; E 13 ; E 14 ; E 21$ \\
\hline Neonate death & 09 & E1;E2;E4;E7;E13;E14;E17;E21;E23 \\
\hline Post-neonate death & 03 & E2; E14; E21 \\
\hline Prematurity & 08 & E3; E4; E7; E11; E13; E14; E18; E24 \\
\hline Low weight at birth & 11 & E3; E4;E7; E11; E13; E14;E18; E20;E23; E24; E27 \\
\hline Laboratory and radiological changes & Number of studies & Code of the studies that presented laboratory and radiological alterations* $(n=14)$ \\
\hline Anemia & 11 & E1;E5;E11;E12;E15;E20; E22; E23; E24; E26; E27 \\
\hline Thrombocytopenia & 08 & E5; E11;E12; E15; E20; E22; E23; E27 \\
\hline Leukocytosis & 07 & E11; E12;E15;E20; E22;E25;E27 \\
\hline Leukopenia & 01 & E12 \\
\hline $\begin{array}{l}\text { VDRL titers twice as high than the } \\
\text { mother birth }\end{array}$ & 03 & E11;E12; E15 \\
\hline
\end{tabular}


Chart 2 (concluded)

\begin{tabular}{|c|c|c|}
\hline $\begin{array}{l}\text { Complications and manifestations of } \\
\text { congenital syphilis }\end{array}$ & & Analyzed studies $(n=27)$ \\
\hline Alterations in liquor puncture & 07 & E3; E11;E12;E15; E19; E20; E22 \\
\hline Findings in the radiography of long bones & 10 & E1;E3;E12;E15;E19;E20;E22; E24; E26; E27 \\
\hline Early manifestations & Number of studies & Codes of the studies that presented early manifestations* $(n=15)$ \\
\hline Hepatomegaly & 14 & E5; E9; E11; E12; E15; E18; E19;E20; E22; E23; E24; E25; E26; E27 \\
\hline Splenomegaly & 14 & E1; E5; E11;E12;E15; E18; E19;E20; E22; E23; E24; E25; E26; E27 \\
\hline Jaundice & 09 & $E 1 ; E 11 ; E 12 ; E 18 ; E 20 ; E 23 ; E 24 ; E 25 ; E 27$ \\
\hline Serosanguineous rhinitis & 08 & $E 1 ; E 12 ; E 18 ; E 20 ; E 22 ; E 23 ; E 24 ; E 27$ \\
\hline Palmoplantar pemphigus & 12 & E5;E11;E12;E15;E18;E19;E20;E22;E23;E25;E26;E27 \\
\hline Perioral or perianal fissures & 05 & E12; E15; E18; E20; E22 \\
\hline Paleness & 02 & E12; E27 \\
\hline Petechias, purpura, and/or rashes & 05 & $\mathrm{E} 1 ; \mathrm{E} 11 ; \mathrm{E} 12 ; \mathrm{E} 22 ; \mathrm{E} 27$ \\
\hline Lymphadenopathy & 02 & E12; E22 \\
\hline Respiratory suffering & 02 & E12; E23 \\
\hline Pneumonia & 03 & E5; E12; E18 \\
\hline Fever & 02 & E12; E18 \\
\hline Ascites & 03 & E9; E25; E26 \\
\hline Fetal hidropsy & 02 & E12; E23 \\
\hline Generalized edema & 02 & E25; E26 \\
\hline Pseudoparalysis & 01 & E23 \\
\hline Late manifestations & Number of studies & Codes of the studies that presented late manifestations* $(n=3)$ \\
\hline Hutchinson's teeth & 02 & E10; E16 \\
\hline Mulberry molars & 01 & E10 \\
\hline Interstitial keratitis & 01 & E16 \\
\hline Neurological deafness & 02 & E12; E16 \\
\hline Frontal bossing & 01 & E12 \\
\hline Saddle nose & 01 & E12 \\
\hline
\end{tabular}

Note: *The studies may have presented more than one type of outcome; VDRL - Venereal Disease Research Laboratory.

In the 27 articles analyzed, an attempt was made to identify information about the actions that could avoid clinical complications and manifestations of CS in newborns. In 21 studies, it was found that, during prenatal care, many opportunities to prevent against grave outcomes of this infection in the child are not taken advantage off.
The main opportunities for this prevention that were lost were the non-treatment of the pregnant woman during the prenatal ( $\mathrm{n}$ $=9)$, the late diagnoses of pregnant women $(n=4)$, the late start of the prenatal $(n=3)$, pregnant women that were not properly treated for the disease $(n=3)$, and women with high titer levels at time of birth, according to the VDRL $(n=3)$ (Chart 3).

Chart 3 - Avoidability of the clinical complications and manifestations found for congenital syphilis in the studies analyzed

\begin{tabular}{|c|c|c|}
\hline $\begin{array}{c}\text { Lost opportunities related to the avoidability of congenital } \\
\text { syphilis consequences for the baby }\end{array}$ & Number of studies & $\begin{array}{c}\text { Codes of the studies that presented lost } \\
\text { opportunities* (n= 21) }\end{array}$ \\
\hline No prenatal & 2 & $E 12, E 26$ \\
\hline Late prenatal start & 3 & $E 04, E 20, E 24$ \\
\hline No test during the prenatal & 2 & $E 13, E 18$ \\
\hline Late diagnosis & 4 & $E 01, E 07, E 11, E 12$ \\
\hline No treatment during the prenatal & 9 & $E 03, E 06, E 12, E 07, E 13, E 14, E 18, E 19, E 22$ \\
\hline Inadequate treatment & 3 & $E 03, E 12, E 17$ \\
\hline High titer levels at the moment of birth & 3 & $E 20, E 21, E 25$ \\
\hline
\end{tabular}




\section{DISCUSSION}

Although syphilis has existed for millennia and there are studies that bring knowledge about CS, this infection is still a serious public health problem, especially in poor and developing countries. Most findings in the babies were related to lost opportunities to provide assistance to the mother.

Even with the high number of published studies, the actual magnitude of the damage this infection brings to Brazil may still be unknown ${ }^{(14)}$. Stillbirths and neonate death are among the most common negative outcomes in the articles found, and the systematic review and meta-analyses included show that this outcome is more likely in pregnant women with syphilis ${ }^{(5-7)}$, and in those who were not treated or who were not treated properly ${ }^{(19)}$.

Regarding laboratory and radiologic changes in the children, it stands out that all children whose mothers with syphilis were not treated or not treated properly must undergo the VDRL test, a hemogram, a radiography of the long bones, and liquor puncturing, even if they show no symptoms at birth ${ }^{(36)}$. A study carried out in Porto Alegre, in Rio Grande do Sul (RS), Brazil, showed that $25 \%$ of the children who were born with no symptoms had an alteration in at least one of these exams ${ }^{(8)}$.

Radiographic findings have an important role in the diagnosis of CS. In the Netherlands, a study found radiologic changes in eight out of ten children with CS signs ${ }^{(3)}$. These changes varied from a light periosteal reaction through the decalcification of the long bones to characteristics consistent of osteomyelitis. In Brazil, the proportions of changes in radiographies of long bones were of $1.6 \%$ in the state of Paraná $(P R)^{(15)}$ and $9.6 \%$ in Rio de Janeiro $(R J)^{(13)}$.

It is important for health professionals to be attentive to other findings that are not typical of children with CS. These findings, despite not being specific of these cases, can indicate complications or associated pathologies. This review found cases of children with CS who showed signs of liver dysfunction ${ }^{(16)}$, kidney problems consistent with nephrotic syndrome ${ }^{(35)}$, increased creatinine, and histopathological lesions in kidney biopsies ${ }^{(16,33-34)}$.

Another important aspect is identifying early clinical manifestations of CS by a minute physical examination of the newborn, aiding in the diagnostic and in providing a timely response. This contributes for a reduction of sequelae from the infection, especially considering that children who are symptomatic at birth are more likely to die when compared to asymptomatic ones ${ }^{(14)}$.

Regarding late CS manifestations, a case study carried out in India with two children showed that the only CS evidences were Hutchinson's teeth and mulberry molars ${ }^{(21)}$. These manifestations present as deformed upper middle incisors, in the form of screwdrivers, little flags, or beveled, generally accompanied by molars that are similar to mulberries due to their multiple cuspids. The authors alert that the presence of mulberry molars makes them highly susceptible to cavities and can lead to the early loss of teeth. As a result, these children need dental evaluation and monitoring ${ }^{(21,24)}$.

Other findings, such as frontal bossing and saddle nose, in addition to delays in development, were found by a research from Porto Alegre, Rio Grande do Sul, Brazil ${ }^{(8)}$. In that study, children who presented laboratory changes at birth were 20 times more likely to develop late CS sequelae. Considering the above, it is noteworthy that there are still late diagnoses for CS. The causes for this may indicate shortcomings in the strategies of prevention and treatment of the different levels of attention ${ }^{(37)}$.

Most studies evaluated the newborns during the ten days of hospitalization in the maternity for CS treatment, maybe due to the difficulties in getting to these children after their hospital discharge. Outpatient follow up seems to be challenging, and the few researches on it show that these children often interrupt their follow up. In Merseyside, England, in 1985, 2 out of 7 children with CS, who should be monitored in outpatient clinics up to their 3rd year of age, only came to their evaluation once ${ }^{(32)}$. More recently, in Brazil, studies in the cities of Porto Alegre (RS) (8) and Curitiba (Paraná - PR) ${ }^{(15)}$ showed that the proportion of children who were not present in the health services for their follow up is large.

All studies that analyzed clinical findings in children with early CS showed some shortcoming in the management of care to the pregnant woman, especially when related to tracking, diagnosing, and providing proper treatment to the mothers as soon as possible ${ }^{(8,28,32)}$. Researches carried out in Chile, Mexico, and England exposed cases of early CS in which the mothers were only reactive to the second test applied to them or during birth $^{(22-23,27-28,32)}$. These women may have been infected during pregnancy and present high titer levels at the moment of birth, corresponding to an early stage of the infection.

Once the opportunities to prevent CS are lost during the prenatal care, its late complications in the newborns can be prevented, as long as these babies are properly managed when they are born. In the state of Minas Gerais (MG), Brazil, a study showed that the VDRL was not carried out for $25.8 \%$ of babies, while $42.2 \%$ did not undergo a hemogram, radiographies of the long bones, or liquor puncturing ${ }^{(17)}$. The health services may present difficulties to the guarantee all exams necessary to diagnose CS, which, in the long term, may lead to the increase in the cases of children with serious sequelae.

The transmission of syphilis to the baby is related to the clinical stage of the mother's infection, and can reach $100 \%$ when the infection is recent ${ }^{(38-39)}$. High titer levels in non-treponemal tests in the mother indicate that the infection is recent and increase the likelihood of negative outcomes. In Shanghai, China, pregnant women whose titer levels were $\geq 1: 16$ in reacting to the Rapid Plasma Reagin (RPR) exam showed higher levels of CS when compared to those with $\geq 1: 8$ titer levels ${ }^{(24)}$. Furthermore, in Africa, stillbirth is associated with high VDRL titration ${ }^{(26,29)}$.

These findings call our attention to how important it is to improve both the prenatal coverage and the early tracking of the pregnant women; in these occasions, the opportunity to test and treat cannot be lost. Diagnosing and starting to treat syphilis as early as possible, preferably in the first trimester of pregnancy, avoids the prolonged exposure of the baby to the treponema. As a result, it should be mentioned that improving prenatal care is essential to prevent negative CS outcomes, considering that a study carried out using the World Health Organization database found that $66 \%$ of adverse effects involved children whose mothers went to prenatal examinations ${ }^{(6)}$.

In the United States, a study found how important it is to treat pregnant women with syphilis to prevent complications in the newborn. Through ultrasonography, it was possible to find that 
the number of abnormal findings (hepatomegaly, placentomegaly, polyhydramnios, ascites, and changes in the doppler evaluation of the middle cerebral artery) in fetuses after the mother was treated ${ }^{(20)}$.

It should be noted that, even when there are shortcomings in the attention to the pregnant woman, it is possible to reduce CS complications when the newborn is diagnosed and treated as early as possible. A cohort carried out in SC followed cases of children up to 5 years old and found that some children showed alterations at birth, but did not develop sequelae because they started their treatment in their first seven days of life ${ }^{(8)}$.

\section{Study limitations}

A limiting factor of this study is the fact that literature was not exhaustively analyzed, since many researches were not openly available in full. Furthermore, some studies were case reports, which reduces their scope and/or the relevance of the inferences that can be made from these individual findings.

\section{Contributions to the fields of Nursing, Health or Public Policy}

This study is an important contribution, as it compiles and presents the complications from CS, indicating that they could be avoided. As a result, it can be an asset in the elaboration of public health policies that could help improving the quality of prenatal care. It can also give support to health workers in the identification of clinical manifestations, helping to provide early diagnoses, to adequately manage the newborn, and to reduce grave CS sequelae.

\section{CONCLUSIONS}

The scientific evidence analyzed here shows severe negative outcomes of CS, such as stillbirths, neonate deaths, and low weight at birth, in addition to radiological and laboratory changes, and a high diversity of early and late clinical manifestations. These outcomes could be avoided, considering that opportunities to diagnose early and treat the pregnant woman were lost during prenatal care.

\section{REFERENCES}

1. World Health Organization (WHO). The Global elimination of congenital syphilis: rationale and strategy for action [Internet]. Geneva: WHO; 2007 [cited 2019 Apr 8]. Available from: https://apps.who.int/iris/bitstream/handle/10665/43782/9789241595858_eng.pdf?sequence=1

2. World Health Organization (WHO). Global guidance on criteria and processes for validation: elimination of mother-to-child transmission of HIV and syphilis [Internet]. Geneva:WHO; 2014 [cited 2019 Apr 8]. Available from: https://apps.who.int/iris/bitstream/hand le/10665/259517/9789241513272-eng.pdf?sequence=1

3. Wijesooriya NS, Rochat RW, Kamb ML, Turlapati P, Temmerman M, Broutet N, et al. Global burden of maternal and congenital syphilis in 2008 and 2012: a health systems modelling study. Lancet. 2016; 4(8):525-33. https://doi.org/10.1016/S2214-109X(16)30135-8

4. Organização as Nações Unidas (ONU). Centro de Informação Regional das Nações Unidas para a Europa Ocidental. Guia sobre Desenvolvimento Sustentável: 17 objetivos para transformar o nosso mundo [Internet]. UNRIC, 2016 [cited 2019 Apr 8]. Available from: https://www.unric.org/pt/images/stories/2016/ods_2edicao_web_pages.pdf

5. Gomez GB, Kamb ML, Newman LM, Mark J, Broutet N, Hawkes SJ. Untreated maternal syphilis and adverse outcomes of pregnancy: a systematic review and meta-analysis. Bull World Health Organ. 2013; 91:217-26. https://doi.org/10.2471/BLT.12.107623

6. Newman L, Kamb M, Hawkes S, Gomez G, Say L, Seuc A, et al. Global estimates of syphilis in pregnancy and associated adverse outcomes: analysis of multinational antenatal surveillance data. PLoS Med. 2013;10(2):e1001396. https://doi.org/10.1371/journal.pmed.1001396

7. Domingues RMSM, Leal MC. Incidência de sífilis congênita e fatores associados à transmissão vertical da sífilis: dados do estudo Nascer no Brasil. Cad Saúde Pública. 2016;32(6):e00082415. https://doi.org/10.1590/0102-311X00082415

8. Lago G, Vaccari A, Fiori RM. Clinical features and follow-up of congenital syphilis. Sex Transm Dis. 2013;40(2):85-94. https://doi.org/10.1097/ OLQ.0b013e31827bd688

9. World Health Organization (WHO). Guidelines for the treatment of Treponema pallidum (syphilis) [Internet]. Geneva: WHO; 2016 [cited 2019 Apr 8]. Available from: https://apps.who.int/iris/bitstream/handle/10665/249572/9789241549806-eng.pdf

10. Ganong LH. Integrative reviews of nursing research. Res Nurs Health. 1987; 10(1):1-11. 2

11. Whittemore R. Combining evidence in nursing research: methods and implications. Nurs Res. 2005;54(1):56-62.

12. Melnyk BM, Fineout-Overholt E. Evidence-based practice in nursing and health: a guide to best practice. Philadelphia: Wolters Kluwer; Lippincott Williams \& Wilkins Health; 2011.

13. Souza LFM, Monteiro PM, Mota AS, Passos MRL, Pellegrini Jr EM. Analysis of congenital syphilis cases notification in a reference hospital of Niterói, Rio de Janeiro State, from 2008 to 2015. DST J Bras Doenças Sex Transm. 2017;29(1):17-21. https://doi.org/10.5533/ DST-2177-8264-201729105

14. Cardoso ARP, Araújo MAL, Andrade RFV, Saraceni V, Miranda AE, Dourado MIC. Underreporting of congenital syphilis as a cause of fetal and infant deaths in Northeastern Brazil. PLoS ONE. 2016;11(12):e0167255. https://doi.org/10.1371/journal.pone.0167255

15. Feliz MC, Medeiros ARP, Rossoni AM, Tahnus T, Pereira AMVB, Rodrigues C. Adherence to the follow-up of the newborn exposed to syphilis and factors associated with loss to follow-up. Rev Bras Epidemiol. 2016;19(4):727-39. https://doi.org/10.1590/1980-5497201600040004

16. Ferreira ST, Correia C, Marçal M, Tuna ML. Skin rash: a manifestation of early congenital syphilis. BMJ Case Reports. 2016;bcr2016216148. https://doi.org/10.1136/bcr-2016-216148 
17. Lafetá KRG, Martelli Jr H, Silveira MF, Paranaíba LMR. Maternal and congenital syphilis, underreported and difficult to control. Rev Bras Epidemiol. 2016;19(1):63-74. https://doi.org/10.1590/1980-5497201600010006

18. Dou L, Wang X, Wang F, Wang Q, Qiao Y, Su M, et al. Epidemic Profile of Maternal Syphilis in China in 2013. BioMed Research International. 2016;ID9194805. https://doi.org/10.1155/2016/9194805

19. Arnesen L, Martínez G, Mainero L, Serruya S, Durán P. Gestational syphilis and stillbirth in Latin America and the Caribbean. Int J Gynaecol Obstet. 2015;128(3):241-5. https://doi.org/10.1016/j.ijgo.2014.09.017

20. Rac MWF, Bryant SN, McIntire DD, Cantey JB, Twickler DM, Wendel Jr GD et al. Progression of ultrasound findings of fetal syphilis after maternal treatment. Am J Obstet Gynecol. 2014;211(4):426e1-e6. https://doi.org/10.1016/j.ajog.2014.05.049

21. Chowdhary N, Rani BSK, Mukunda KS, Kiran NK. Early detection of congenital syphilis. J Indian Soc Pedod Prev Dent. 2014;32(4):333-7. https://doi.org/10.4103/0970-4388.140969

22. Cavagnaro FSM, Pereira TR, Pérez CP, Vargas FDV, Sandoval CC. Sífilis congénita precoz: a propósito de 2 casos clínicos. Rev Chile Pediatr. 2014;85(1):86-93. https://doi.org/10.4067/S0370-41062014000100012

23. Arriagada D, Donoso A, Cruces P, Díaz F. Congenital syphilis: presenting as septic shock alter the neonatal period. Rev Chile Infectol. 2012;29(5):558-63. https://doi.org/10.4067/S0716-10182012000600017

24. Pessoa L, Galvão V. Clinical aspects of congenital syphilis with Hutchinson's triad. BMJ Case Rep. 2011;bcr1120115130. https://doi.org/10.1136/ bcr.11.2011.5130

25. Zhu L, Qin M, Du L, Xie RH, Wong T, Wen SW. Maternal and congenital syphilis in Shanghai, China, 2002 to 2006. Int J Infect Dis. 2010;14(Suppl 3):e45-8. https://doi.org/10.1016/j.ijid.2009.09.009

26. Krüger C, Malleyeck I. Congenital syphilis: still a serious, under-diagnosed threat for children in resource-poor countries. World J Pediatr. 2010;6(2):125-31. https://doi.org/10.1007/s12519-010-0028-z

27. Reyes JA, Chorbadjian AG, Parada CMA, Turrys CJ, Bravo CN, Araya FCG. Sífilis congénita: optimizando el diagnóstico en 191 neonatos de madres seropositivas. Rev Chile Infectol. 2004;21(4):307-11. https://doi.org/10.4067/S0716-10182004000400004

28. Peña A, Cardiel-Marmolejo LE, Matamoros-Márquez M, Iturbide-Cruz LA, Ávalos-Martínez JL, García HJ. Sífilis congénita: presentación de un caso y revisión de la literatura. Rev Méd Hosp Gen Méx [Internet]. 2001 [cited 2019 Apr 8];64(4):240-5. Available from: http://www. medigraphic.com/pdfs/h-gral/hg-2001/hg014i.pdf

29. McDermott J, Steketee R, Larsen S, Wirima J. Syphilis-associated perinatal and infant mortality in rural Malawi. Bull World Health Organ [Internet]. 1993 [cited 2019 Apr 8];71(6):773-80. Available from: https://www.ncbi.nlm.nih.gov/pmc/articles/PMC2393540/pdf/bullwho00039-0115.pdf

30. Boot JM, Orange AP, Menke HE, Van Eijk RV, Stolz E. Congenital syphilis in The Netherlands: diagnosis and clinical features. Genitourin Med. 1989;65(5):300-3. https://doi.org/10.1136/sti.65.5.300

31. Chawla V, Pandit PB, Nkrumah FK. Congenital syphilis in the newborn. Arch Dis Child. 1988;63(11):1393-4. https://doi.org/10.1136/adc.63.11.1393

32. Ewing Cl, Roberts C, Davison DC, Arya OP. Early congenital syphilis still occurs. Arch Dis Child. 1985;60(12):1128-33. https://doi.org/10.1136/ adc.60.12.1128

33. Aguayo IT, Martínez GD, Munzenmaycr JB, Roscmberg HG, Fuente-Alba JAG. Síndrome Nefrótico Secundario a Lues Congénita. Rev Chile Pediatr. 1985;56(2):103-7. https://doi.org/10.4067/S0370-41061985000200009

34. Wiggelinkhuizen J, Kaschula ROC, Uys CJ, Kuijten RH, Dale J. Congenital syphilis and glomerulonephritis with evidence for immune pathogenesis. Arch Dis Child. 1973;48(5):375-81. https://doi.org/10.1136/adc.48.5.375

35. Freiman I, Super M. Thrombocytopenia and congenital syphilis in South African Bantu infants. Arch Dis Child. 1966;41(215):87-90. https:// doi.org/10.1136/adc.41.215.87

36. Ministério da Saúde (BR). Secretaria de Vigilância em Saúde. Departamento de Doenças de Condições Crônicas e Infecções Sexualmente Transmissíveis. Protocolo Clínico e Diretrizes Terapêuticas para Prevenção da Transmissão Vertical do HIV, Sífilis e Hepatites Virais [Internet]. Brasília, DF (BR): Ministério da Saúde, 2019 [cited 2010 May 19]. Available from: http://www.aids.gov.br/pt-br/pub/2015/ protocolo-clinico-e-diretrizes-terapeuticas-para-prevencao-da-transmissao-vertical-de-hiv

37. Blencowe H, Cousens S, Kamb M, Berman S, Gramado AE. Lives Saved Tool supplement detection and treatment of syphilis in pregnancy to reduce syphilis related stillbirths and neonatal mortality. BMC Public Health. 2011;11(Suppl 3):S9. https://doi.org/10.1186/1471-2458-11-S3-S9

38. Nascimento MI, Cunha AA, Guimarães EV, Alvarez FS, Oliveira SRSM, Villas Bôas EL. Gestações complicadas por sífilis materna e óbito fetal. Rev Bras Ginecol Obstet. 2012;34(2):56-62. https://doi.org/10.1590/S0100-72032012000200003

39. Andrade ALMB, Magalhães PVVS, Moraes MM, Tresoldi AT, Pereira RM. Late diagnosis of congenital syphilis: a recurring reality in woman and children health care in Brazil. Rev Paul Pediatr. 2018;36(3):376-81. https://doi.org/10.1590/1984-0462/;2018;36;3;00011 